\title{
Development of Integration Relations Involving Russian Real and Financial Sector Entities
}

\author{
R.M. Kundukchyan a \\ R.R. Gaizatullin b \\ Z.N, Zappartova ${ }^{c}$ \\ N.V.Antonova ${ }^{d}$ \\ abcd Kazan Federal University, Kazan, 420008, Russia
}

\section{Doi:10.5901/mjss.2014.v5n12p69}

\section{Abstract}

The article analyses institutional forms of real and financial organizations integration and offers practical recommendations based on the results of the analysis, which guarantees their efficiency in contemporary Russian economy. Two options of institutional forms of bank and industrial capital integration are offered, the leading role belonging to bank and real economy sector. The author outlines functions of banks as intermediary organizations, offers efficiency factors for interaction between real and financial sectors, creates a strategic map of regional bank and develops a model of integrate holding structure.

Keywords: integrate holding structures, banking sector, lending agencies, real sector entities, government control.

\section{Introduction}

The efficiency of state policy in providing favorable conditions for economic development and implementing innovative scheme for development of commercial entities in non financial sector depends on a number of factors. The enforcement actions on activities of credit institutions as an integral part of government control are of special interest.

The development of financial sector is determined by overall financial standing of world and national economy. The process of globalization and its effect on national measures, industrial development trends, institutional environment efficiency, degree of structural changes completion, income distribution are of primary importance.

Deficient development of theoretical and methodological bases of interaction between industrial and bank capital as a condition of quality reconstruction of Russian economy, set tone for the study as well as its theoretical and practical value.

Rules and mechanisms of capital market processes were the subject of special attention by members of different schools and scientific areas. The first to investigate the essence of capital and its elements were political economists (William Petty François Quesnay, Adam Smith, David Ricardo, Karl Marx, John Stuart Mill). Marks' works set base to the study of essence of industrial and bank capital and their role in market economy.

At the same time vast majority of publications $[3 ; 5 ; 8 ; 11]$ are dedicated to separate aspects of the problem under investigation: application problems of stock market performance, banking power formation, government monetary and credit policy assessment, etc. All the lines of analysis mentioned above give rather detailed characteristics of different forms of industrial and bank capital integration, but they cannot be observed as a thorough theoretical end methodological research of its essences and role in the context of Russian economy.

\section{Methodology}

The study is based on theoretical and methodological concepts of fundamental and applied scientific researches in regional management strategic management, banking, and company development assessment theory, by the leading Russian and foreign scholars.

The following general methodological principles of scientific research are used in the study: objectivity principle, which requires an overall factor record and adequate scientific approaches; continuous development of the investigated issues and singling out the basic ones, which affect the result of the study; systematic and integral approach to analysis 
of the phenomena.

In contemporary economy the real scope of economic entities expand beyond the limits of the legitimate company due to high transactional expenditures. The structure of the economic area changes so that contacts between juristically independent persons may cause creation of a "quasi-company" as a form of realization of recombined property. In distinguishing between real and formal property rights it signifies that contacts between business entities (both explicit and implicit) play an important role both as a coordinating tool in economy and the basis of corporate integration. Nowadays the institutional form of implementing industrial and bank capital consolidation is integral formation. It is a system of contacts between officially independent economic entities which makes it possible to combine and use the resources in a rational manner $[4 ; 6]$. It is performance of a long term relational contract that dominates in intercompany networking cooperation.

\section{Result}

Development of integrate relations involving real and financial entities is fostered by evolution of intercompany relations in financial sector through intermediaries. Steps of financial intermediation evolution on financial market are shown in table 1.

Table 1: Intermediation evolution on financial market

\begin{tabular}{|l|l|l|}
\hline \multicolumn{1}{|c|}{ Step of economic development } & \multicolumn{1}{c|}{ Form of intermediary } & \multicolumn{1}{c|}{ Structure of financial intermediary } \\
\hline $\begin{array}{l}\text { I. Development of industrial competitive } \\
\text { economy }\end{array}$ & $\begin{array}{l}\text { Banking market } \\
\text { intermediation }\end{array}$ & 1. Universal and specialized banks \\
\hline II. Industrial competitive economy & Stock market intermediation & $\begin{array}{l}\text { 1. Universal and specialized banks } \\
\text { 2. Para-banking organizations }\end{array}$ \\
\hline III. Financial economy & Stock market intermediation & $\begin{array}{l}\text { 1. Universal and specialized banks } \\
\text { 2. Para-banking organizations } \\
\text { 3. integrate financial intermediaries ("financial } \\
\text { supermarkets") }\end{array}$ \\
\hline
\end{tabular}

Change in membership and forms of interaction between financial institutions in the course of financial intermediation evolution, confirms need for financial intermediaries in terms of macro economy. At the present stage of financial economic development, finance market intermediation gains relevance in the process of structural changes in the world economy, bank, fund and insurance segments integration, and financial market relaxation. The role of financial market as an intermediary increases due to informatization which leads to versatility of financial centers, emergence of new market members and its restructuring.

Studies on financial market performance in Russia and abroad point to appearance of new implications of bank and industrial integration in view of the passage to a new orbit of globalization and internationalization of the global economy $[7 ; 9,16]$. Among the latest we should focus on: multiplicative effect, which means possible control over other economic entities' capital by means of their own modest capital; prevention of external hostile takeover; promotion of economic entities' competitiveness in the context of the World Economic Area globalization; financial deepening and financial business improving in the field of cooperation with non financial sector, etc. Contradictions in views over essence of integrate entities include clash of long-term investment interests between real sector economic entities, which have absolute authority over (borrower's) physical resources, and lending agencies which place a priority on legal power to the bank property capital. As a consequence, it separates from the real sector enabling banking companies implement their own interests by improving their revenue and expenditure pattern, not related to changes in performance indicator of industries' production possibilities. This contradiction is fixed in opportunistic conduct of bank capital entities, ad conflict between institutions controlling real and banking economy sectors. This conflict develops into formation of artificial capital, which constitutes corporations' establishment profit and state emissive profit when exceeding the real capital.

Typically, in integrate holding organizations there is economical dependence between the parent company and the affiliated companies. This dependence can be based on prevailing interest of the head company in the establishment capital of the affiliated one, and on the contract or other circumstances, allowing the parent company shape or influence the decisions of the affiliated company. Alternatively, these companies may have equal rights and mutual influence on each other.

As integrate holding structures are not juridical entities, the official figures reflecting their numerical trends in 
Russian regions are missing. Fraction of capital issues in commercial banks' assets reflects to some degree stage of their involvement into integrate structures. Emergence of IHS as a market entity will make it possible to render state aid to create and develop it. The Central Bank of the Russian Federation can grant benefits to the banks-members including debt provisioning rate cut and other changes in order to increase their investment activeness.

Recent growth in the number of IHS in Russian regions has several reasons. Firstly, under conditions of government budget cut IHS is considered as a resource leveraging tool. Secondly, IHS take priority over financial industrial companies where banks fulfilled the function of cash processing center. Thirdly, low level of banking services supply in some Russian regions (Appendix 1).

The Volga Region Federal District (VRFD) is the second largest region in number of credit companies, their branches and supplementary offices after the Central Federal District, which comprises Moscow city and the Moscow region - 4,268 credit companies - (almost 12\% of the total number in the RF). The Volga Region Federal District implements diversified banking: the operating credit institutions' assets (the five largest banks' assets to regional total assets ratio) make $41.3 \%$ against $46.6 \%$ national average, $65.3 \%$ in the Siberia Federal District, $64.2 \%$ in Northwestern Federal District and $53.4 \%$ in the Central Federal District. High potential of VRFD banking services market is determined by availability of currency in hand, lower rate of dampening of economic activity in the real sector amid the crisis [1]. The advantages of integrate holding structures are:

1. Effective reallocation of credit resources into regions with favorable economic situation, maintenance of adequate liquidity position and profit extraction.

2. Real sector companies' access to credit resources without quick assets, and to commercial activities history.

3. Flexible customer-oriented reorganization programme.

4. Hands-off financing of innovative activity.

5. Loan debt discounting (restructuring).

6. Minimum cost of banking service delivery.

7. Granting credit to regional and municipal authorities in order to implement purpose-oriented programmes; intermediary functions on stock market, foreign currency market (both exchanging and non - exchange), insurance market, etc.

The analysis conducted enables us to establish two alternatives for institutional integration forms of bank and industrial capital $[11,15]$ where the leading position belongs to the bank and real economy sectors. If bank is the financial center of the group and administers the structure, then it successfully manages bank assets and equities, and handles financial management of the group, which is customary for the majority of integrate holding structures lacking relevant legal position.

Regional bank strategy must be specific, measurable, achievable, relevant to the purpose, timely. According to these principles we can establish a series of the following steps: developing a mission, strategic development framework, setting goals and creating intervention mechanisms. Regional bank's mission is to promote economy and commonwealth of the region by providing high-quality banking services to enterprises - members of the integrate organization, according to high professional and ethic standards which guarantee bank profit, investor's dividends, shareholder's benefit, IHS consolidated profit and fair treatment of bank officials. Then strategic development framework consists in stable competitive edge concept. The regional bank's goals are efficient allocation of resources, fundraising, active and passive banking transactions management, personnel administration, creation of supervisory bodies, bringing the bank duties to notice of the personnel, planning and control; public relations, banking services positioning, promoting new banking product. Implementation arrangements are to establish strategic position, elicit one or several competitive strength sources, build up business concept, and come into contact with the consumer. Creation of development strategy for regional banks in the context of macroeconomic instability makes it possible to work out a bank management system which aims to reduce variability, ambitendency and threshold effect. If implemented, this strategy will provide positive synergetic effect due to integration with real sector companies [16].

As follows from the analysis, we can establish three strategic positions of regional bank as IHS financial center: adapting, formative and conservative (reserving a right to play). According to adaptation policy the bank takes every opportunity to avert certain threats. Formative policy aims to change economic environment, such as offer new banking products and services; develop new competitive win strategies. Conservative policy comprises a number of minimum required actions to keep dominant position on the loan facilities market.

There are several courses of development for a bank as IHS financial center. "Systematic" bank offers depersonalized customer banking; "segmented" bank uses differential approach to meet requirements of a specific consumer segment; "customer's bank" offers custom-tailored service. Of all these the first option is preferable as it presupposes automated data processing and economies of scale. 
A balanced scorecard can help implement efficient bank policy. Due to this policy strategy, mission and aim can be transferred to a set of specific factors, which are instrumental in making decisions in order to provide stable growth of the bank value and satisfy IHS members' customer demands.

BSC structure is created so as to reflect correspondence between goals and metrics of the general group and separately run business units. Thus, BSC method enables us to combine strategic and operation management. All group members are regularly engaged in implementing the strategy. Administration is exercised through scheduling, reporting, BSC control and evaluation as well as motivational management.

Fig.1 shows an IHS member bank planning chart and implementation of its regional network development policy.

\begin{tabular}{|c|c|c|c|c|}
\hline $\begin{array}{l}\text { Financial } \\
\text { Component }\end{array}$ & \multicolumn{2}{|c|}{$\begin{array}{l}\text { Maintenance Of Revenue Position } \\
\text { (ROA, ROE, Прибыль) }\end{array}$} & \multicolumn{2}{|c|}{$\begin{array}{c}\text { Market Expansion } \\
\text { (Regional Market Share As Compared To Rivals) }\end{array}$} \\
\hline $\begin{array}{l}\text { Non-Public } \\
\text { Component }\end{array}$ & \multicolumn{4}{|c|}{$\begin{array}{l}\text { Competitive advantage } \\
\text { 1. Price policy as compared to rivals } \\
\text { 2. Product portfolio policy as compared to rivals } \\
\text { 3. Customer satisfaction } \\
\end{array}$} \\
\hline $\begin{array}{l}\text { Costumer-Related } \\
\text { Component }\end{array}$ & $\begin{array}{l}\text { Focus on requirements } \\
\text { of the market } \\
\text { Price level and product } \\
\text { range satisfying customer } \\
\text { requirements }\end{array}$ & $\begin{array}{c}\text { Cooperation with } \\
\text { regional authorities } \\
\text { Degree of involvement } \\
\text { into regional } \\
\text { programmes }\end{array}$ & $\begin{array}{l}\text { Cooperation with the Central } \\
\text { Bank of the Russian } \\
\text { Federation } \\
\text { Time needed to obtain a } \\
\text { permit from the Central Bank } \\
\text { of the Russian Federation }\end{array}$ & $\begin{array}{c}\text { Cooperation with real sector } \\
\text { сотраnies } \\
\text { Взаимодействие } \\
\text { предприятиями реального } \\
\text { сектора экономики } \\
\text { Fraction of large scale } \\
\text { companies collaborating with the } \\
\text { bank }\end{array}$ \\
\hline $\begin{array}{l}\text { Training And } \\
\text { Development } \\
\text { Component }\end{array}$ & \multicolumn{4}{|c|}{$\begin{array}{l}\text { Able-minded, motivated, technically literate personnel } \\
\text { 1.Focus the personnel on customer demands } \\
\text { 2. Create favorable working environment } \\
\text { 3.Improve staff efficiency }\end{array}$} \\
\hline
\end{tabular}

Fig.1. Regional bank planning chart

One of the financial sector basic tools is crediting. In order to evaluate national finance market ability to satisfy real sector demands, let us compare the number of credits granted by the national financial sphere with the number of credits taken out by the real sector (FS). This index enables us to assess financial sector efficiency. It can be calculated in the following manner:

Credits granted by the national financial sector, \% GDP

FS = Loans taken out by the national real sector, \% GDP

We can consider financial sector successful if this index is greater than or equal to 1.

\section{Conclusion}

The driving force which fosters Russian integration processes involving banking and real sector economy consists in establishing stable ties and increasing weight in economy. Implementation of this tendency facilitates survivability providing members' mutual help and state support; ability to restore broken technological links in industry; decrease in credit, investment and system risk; reduction of debt to national budget and developing a recovery base for sectoral management of industry and economy as a whole. In its turn it contributes to diversification and reduction of corporate risks, forming competitive position; gaining supplementary income based on informational effect of the merger, which implies deliberate release of information about the prospective merger as a successful undertaking, etc. By creating integrate holding structures and increasing their role in real and financial sectors interaction can contribute to innovationoriented economic progress.

\section{References}

Fakhrutdinova, E., Kolesnikova, J., Yurieva, O., Kamasheva, A. The commercialization of intangible assets in the information society/l World Applied Sciences Journal. Volume 27, Issue 13, 2013, Pages 82-86.

The RF banking sector development trends overview (end of 2012 - beginning of 2013). [web page]. Available: http://http://www.veb.ru. 
Official site of the Central Bank of the Russian Federation [web page]. Available: http://www.cbr.ru.

Allen F., Santomero A. The Theory of Financial Intermediation // Journal of Banking and Finance.1997.Vol. 21. pp. 1461-1485.

Safiullin M.R., Samigullin I.G. and Safiullin L.N. Model of Management of Competitiveness of a Machine-building Complex// World Applied Sciences Journal, 27(13), 2013, pp. 212-216.

Kramin M.V., Safiullin L.N., Kramin T.V., Timiryasova A.V. Drivers of economic growth and investment attractiveness of Russian regions. Life Science Journal 2014; 11(6s): $526-530$.

Ajupov A.A. Risk-Engineering, As an Element of Financial Engineering in the Market of Innovative Financial Products, 27(13), 2013, pp. 5-9.

Calomiris C., Karenski J. "The Bank Merger Wave of the 1990s: Nine Case Studies". -University of Illinois, 1996.

Gainova R.A., Shaidullin R.N., Safiullin L.N. and Maratkanova E.M. Infrastructural Component in Maintenance of Competitiveness of Region// World Applied Sciences Journal, 27(13), 2013, pp. 97-101.

Cornett M., Tehranian H., Changes in Corporate Performance Associated with Bank Acquisitions", Journal of Financial Economics, 1992, Vol. 31, pp. 211-234.

Panasyuk M.V., Pudovik E.M., Sabirova M.E. Problems of labor market of modern Russia in conditions of stable economic growth. Life Science Journal 2014; 11(6s): 487 - 489.

Fakhrutdinova E., Severyanov O., Shigabutdinov A., Fakhrutdinov R. The crisis of 1998 in Russia: political intervention and its implications. Life Science Journal 2014; 11(6s): 442 - 447.

Diamond D.W., Dybvig P.H. Bank Runs, Deposit Insurance, and Liquidity // Journal of Political Economy. 1983. Vol. 91. No 3. P. 401419.

Ennis H.M., Keister T. Bank Runs and Institutions: The Perils of Intervention // American Economic Review. 2009. Vol. 99. No 4. P. 1588-1607.

Frederick C. Schadrack, Leon Korobow The basic elements of bank supervision. Lectures, At Fairfield University Fairitld, Connecticut, Federal Reserve Bank of New York, July 1993.

Isaeva, T.N., Safiullin, L.N., Bagautdinova, N.G., Shaidullin, R.N. Aspects of a multi-level study of competitive performance of objects and subjects of economic management // World Applied Sciences Journal, 27(13), 2013, 116-119.

\section{Appendix 1}

Banking services supply in Volga Region Federal District (VRFD) on 1/06/2013 [2]

\begin{tabular}{|c|c|c|c|c|c|c|c|c|c|c|c|c|}
\hline Regions & 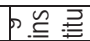 & O & 들 ज顿 & हूळ & $\overline{\mathrm{j}} \mathrm{\underline { \textrm {J } }} \cong$ & $e^{-}$읕 & $\pi$ 읕 & $\stackrel{0}{\underline{E}}$ & 䟠 & 폴 읃 & 응 $\times$ & 옹 \\
\hline $\begin{array}{l}\text { The Republic Of } \\
\text { Bashkortostan }\end{array}$ & 676 & $\begin{array}{l}173 \\
746\end{array}$ & $\begin{array}{l}190 \\
878\end{array}$ & 75952 & 622 & 4053 & $\begin{array}{c}10 \\
942\end{array}$ & 0,98 & 0,36 & 0,70 & 0,57 & 0,61 \\
\hline The Republic Of Marij El & 71 & 23709 & 21596 & 8260 & 52 & 703 & 5803 & 0,60 & 0,58 & 0,95 & 0,68 & 0,69 \\
\hline $\begin{array}{l}\text { The Republic Of } \\
\text { Mordovia }\end{array}$ & 139 & 36456 & 34960 & 11780 & 70 & 840 & 5789 & 0,98 & 0,67 & 1,15 & 0,81 & 0,88 \\
\hline $\begin{array}{c}\text { The Republic Of } \\
\text { Tatarstan }\end{array}$ & 573 & $\begin{array}{l}395 \\
374\end{array}$ & $\begin{array}{l}332 \\
600\end{array}$ & $\begin{array}{l}101 \\
007\end{array}$ & 745 & 3763 & $\begin{array}{c}11 \\
539\end{array}$ & 0,90 & 0,68 & 1,02 & 0,78 & 0,84 \\
\hline The Udmurtian Republic & 205 & 97336 & 89589 & 28192 & 201 & 1533 & 7427 & 0,79 & 0,62 & 1,02 & 0,83 & 0,80 \\
\hline The Chuvashi Republic & 118 & 53026 & 58846 & 19413 & 113 & 1283 & 6309 & 0,54 & 0,60 & 1,19 & 0,80 & 0,75 \\
\hline The Perm Territory & 384 & $\begin{array}{l}200 \\
893\end{array}$ & $\begin{array}{l}209 \\
905\end{array}$ & 71049 & 484 & 2718 & $\begin{array}{c}12 \\
853\end{array}$ & 0,83 & 0,53 & 0,99 & 0,68 & 0,74 \\
\hline The Kirov Region & 175 & 51807 & 57317 & 22575 & 119 & 1413 & 7067 & 0,73 & 0,56 & 1,11 & 0,76 & 0,76 \\
\hline $\begin{array}{c}\text { The Nizhni Novgorod } \\
\text { Region }\end{array}$ & 484 & $\begin{array}{l}259 \\
199 \\
\end{array}$ & $\begin{array}{l}244 \\
027\end{array}$ & 98744 & 469 & 3360 & 9747 & 0,85 & 0,71 & 1,19 & 1,01 & 0,92 \\
\hline The Orenburg Region & 288 & 85814 & 88788 & 38199 & 369 & 2119 & 7700 & 0,80 & 0,30 & 0,55 & 0,78 & 0,57 \\
\hline Penza Region & 173 & 43733 & 44505 & 22425 & 112 & 1388 & 7090 & 0,74 & 0,50 & 0,91 & 0,76 & 0,71 \\
\hline Samara Region & 470 & $\begin{array}{l}372 \\
389 \\
\end{array}$ & $\begin{array}{l}279 \\
533\end{array}$ & $\begin{array}{l}121 \\
935\end{array}$ & 603 & 3173 & $\begin{array}{c}13 \\
640 \\
\end{array}$ & 0,87 & 0,79 & 1,06 & 0,94 & 0,91 \\
\hline Saratov Region & 310 & $\begin{array}{l}110 \\
446\end{array}$ & 98769 & 51410 & 247 & 2584 & 7172 & 0,71 & 0,57 & 0,92 & 0,93 & 0,77 \\
\hline Ulianovsk Region & 202 & 44244 & 48136 & 20304 & 125 & 1312 & 7618 & 0,91 & 0,45 & 0,89 & 0,68 & 0,71 \\
\hline $\begin{array}{c}\text { Volga Region Federal } \\
\text { District }\end{array}$ & $\begin{array}{c}4 \\
268 \\
\end{array}$ & $\begin{array}{c}1948 \\
171 \\
\end{array}$ & $\begin{array}{c}1799 \\
451 \\
\end{array}$ & $\begin{array}{l}691 \\
246 \\
\end{array}$ & $\begin{array}{c}4 \\
331 \\
\end{array}$ & $\begin{array}{c}30 \\
242 \\
\end{array}$ & 9650 & 0,83 & 0,58 & 0,95 & 0,79 & 0,78 \\
\hline
\end{tabular}


